\title{
Klasifikasi Pneumonia Pada Citra X-Rays Paru-Paru Menggunakan GLCM Dan LVQ
}

\author{
Jimmi Lin*, Hafiz Irsyad ${ }^{2}$ \\ ${ }^{1,2}$ STMIK GI MDP, Jalan Rajawali No.14 Palembang, 0711-376400 \\ ${ }^{3}$ Jurusan Teknik Informatika, STMIK MDP Palembang \\ e-mail: *13immilin@mhs.mdp.ac.id, ${ }^{2}$ hafizirsyad@mdp.ac.id
}

\begin{abstract}
Abstrak
Pneumonia merupakan salah satu penyakit infeksi saluran pernafasan yang ditanda dengan peradangan pada satu atau kedua paru-paru yang dapat disebabkan oleh jamur, virus, dan bakteri yang menyebabkan kantung udara sulit menyerap oksigen. Salah satu cara yang dapat digunakan untuk mendeteksi adanya penyakit pneumonia adalah dengan foto rontgen, hasil foto rontgen akan dianalisis oleh orang yang ahli dalam bidang tersebut untuk memastikan apakah adanya pneumonia atau tidak. Penelitian ini dilakukan dengan tujuan untuk mengklasifikasikan hasil $x$-rays kedalam sebuah program untuk mengetahui apakah terdapat pneumonia atau tidak. Metode yang digunakan untuk ekstraksi fitur adalah Gray Level Co-Occurrence Matrix (GLCM) dengan arah $0^{\circ}, 45^{\circ}, 90^{\circ}, 135^{\circ}$ dan metode klasifikasi Learning Vector Quantization (LVQ). Proses sebelum dilakukan klasifikasi yaitu melakukan resize terlebih dahulu, selanjutnya dilakukan ekstraksi fitur menggunakan Gray Level CoOccurrence Matrix (GLCM) dan di klasifikasi menggunakan Learning Vector Quantization (LVQ) dengan akurasi data train terbaik sebesar 89,714\% dan akurasi data test yang terbaik sebesar 74,000\% yang didapat pada pengujian dengan learning rate $=0,4$.
\end{abstract}

Kata kunci-Pneumonia, Resize, GLCM, LVQ

\begin{abstract}
Pneumonia is a respiratory tract infection characterized by inflammation of one or both of the lungs which can be caused by fungi, viruses, and bacteria that make it difficult for the air sacs to absorb oxygen. One way that can be used to detect pneumonia is with x-rays, the results of the $x$-rays will be analyzed by people who are experts in the field to determine whether pneumonia is present or not. This study was conducted with the aim of classifying the $x$-rays into a program to determine whether there was pneumonia or not. The method used for feature extraction is the Gray Level Co-Occurrence Matrix (GLCM) with the directions $0^{\circ}, 45$ $\circ, 90^{\circ}, 135^{\circ}$ and the Learning Vector Quantization (LVQ) classification method. The process before classification is to resize first, then feature extraction using the Gray Level CoOccurrence Matrix (GLCM) and classified using Learning Vector Quantization (LVQ) with the best train data accuracy of $89.714 \%$ and the best test data accuracy of 74,000 \% obtained on testing with a learning rate $=0.4$.
\end{abstract}

Keywords - Pneumonia, Resize, GLCM, LVQ

\section{PENDAHULUAN}

$\mathrm{P}$ neumonia merupakan salah satu penyakit infeksi yang ditandai dengan peradangan pada satu atau kedua paru-paru yang dapat disebabkan oleh jamur, virus, bakteri sehingga menyebabkan kantung udara sulit untuk menyerap oksigen (Misnadiarly, 2008). Pneumonia 
disebabkan oleh kuman Pneumococcus, Staphylococcus, dan Streptococcus. Orang yang rentan terserang pneumonia yaitu anak-anak dengan usia kurang dari 2 tahun, usia lanjut lebih dari 65 tahun, atau orang yang memiliki masalah kesehatan malnutrisi atau gangguan imunologi[1]. Pneumonia dapat diketahui dengan gejala seperti batuk, kesulitan bernapas, dan tarikan dinding dada bagian bawah ke dalam.

Klasifikasi pneumonia menggunakan foto rontgen paru-paru atau sering dikenal dengan istilah foto $x$-rays yang dapat bermanfaat dalam berbagai bidang keilmuan salah satunya kedokteran[2]. Foto $x$-rays ini digunakan oleh radiologi untuk melihat kondisi paru-paru pasien. Namun dengan menggunakan foto $x$-rays ini masyarakat masih kesulitan untuk memahami hasil foto $x$-rays, sehingga membutuhkan orang yang ahli dalam bidang kedokteran untuk membacanya.

Pengenalan objek sampai saat ini sudah banyak diterapkan dalam berbagai bidang. Untuk melakukan pengenalan objek dibutuhkan sebuah fitur yang dapat mewakili identitasnya, Untuk mendapatkan sebuah fitur dari objek diperlukan proses ekstraksi fitur. Ekstraksi fitur bertujuan untuk memperoleh informasi berupa ciri warna, tekstur dan bentuk. Ekstraksi fitur terdiri dari beberapa metode yang digunakan untuk melakukan ekstraksi fitur salah satunya adalah Gray-Level Co-Occurrence Matrix (GLCM). Gray-Level Co-Occurrence Matrix (GLCM) telah digunakan pada penelitian yang membahas Klasifikasi Citra Ikan Berformalin Menggunakan Metode k-NN dan GLCM. Hasil yang didapat untuk mengenali ikan segar sebesar 53\% dan ikan berformalin dikenali sebagai ikan berformalin sebesar 92\%[3].

Proses ketika dilakukan ekstraksi fitur biasanya akan dilakukan segmentasi dan klasifikasi. Metode pengklasifikasian salah satunya adalah Learning Vector Quantization (LVQ). Learning Vector Quantization (LVQ) adalah salah satu jenis jaringan saraf tiruan yang berbasis pembelajaran kompetitif yang terawasi. Suatu lapisan kompetitif akan secara otomatis belajar untuk mengklasifikasikan vektor-vektor input. Apabila vektor-vektor input tersebut akan dikelompokkan dalam kelas yang sama[4].

Jaringan saraf tiruan Learning Vector Quantization (LVQ) dapat diaplikasikan untuk proses diagnosa, karena Learning Vector Quantization (LVQ) merupakan salah satu jenis jaringan yang berbasis kompetitif dimana dari nilai keluaran yang diberikan neuron dalam layer keluaran hanya neuron pemenang saja yang diperhatikan[3]. Metode Learning Vector Quantization (LVQ) telah digunakan pada penelitian[4] yang membahas mengenai Perancangan Sistem Diagnosa Penyakit Saluran Pernapasan Menggunakan Metode Learning Vector Quantization (LVQ). Hasil diagnosa terbaik dengan data yang digunakan sebanyak 109 data, 60 data untuk pelatihan dan 49 data untuk pengujian dengan tingkat keakuratan sebesar 95,92\%.

\section{METODE PENELITIAN}

Berikut adalah beberapa tahapan yang dilakukan dalam penelitian dapat dlilihat pada Gambar 1 berikut: 


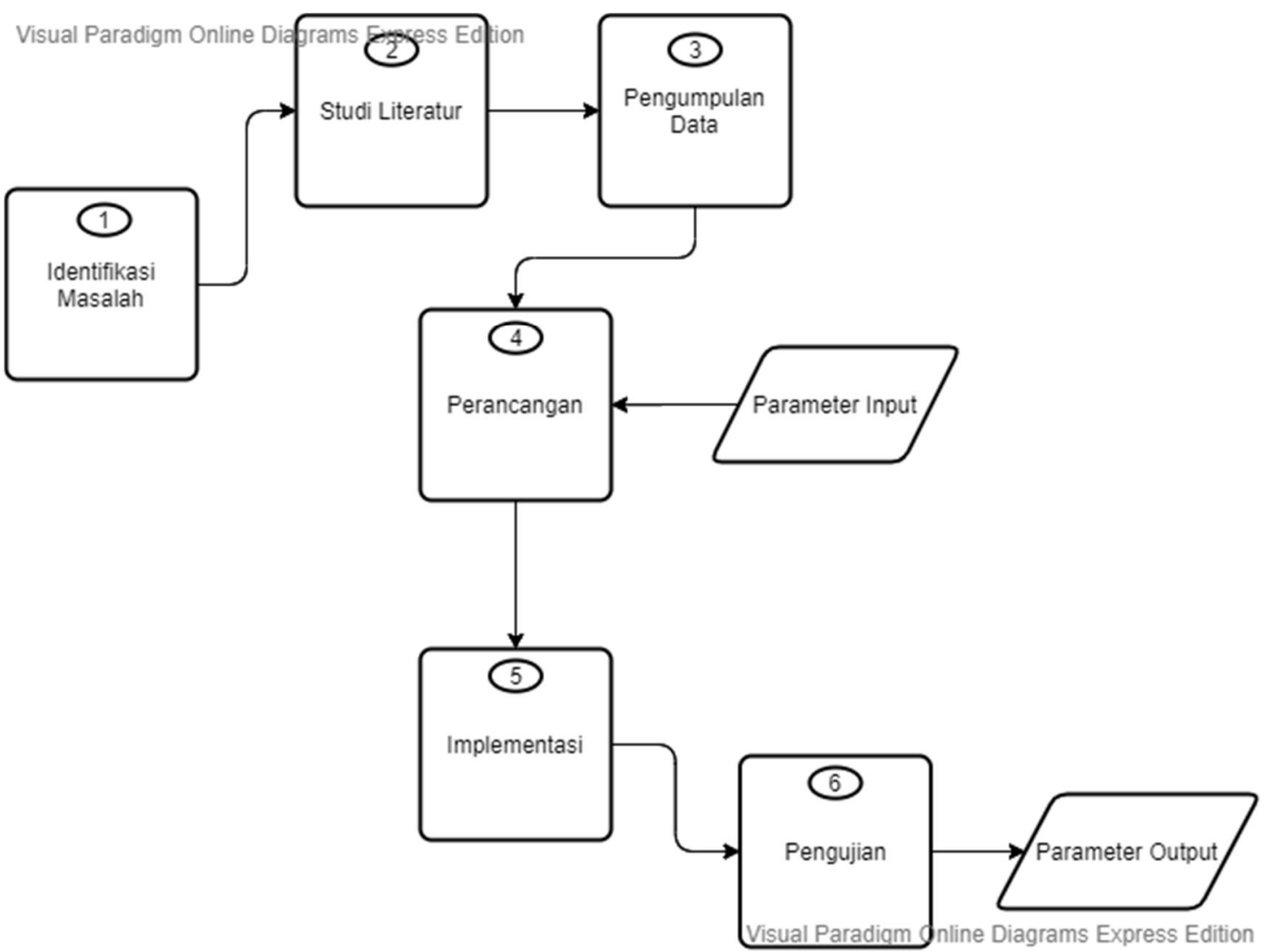

Gambar 1. Kerangka Kerja Penelitian

\subsection{Identifikasi Masalah}

Penelitian dimulai dengan mencari topik-topik mengenai perkembangan tentang klasifikasi penyakit pneumonia. Ruang lingkup dikhususkan pada klasifikasi citra $x$-rays paruparu yang berupa dataset Chest X-Ray Images (Pneumonia). Pada tahapan ini, dilakukan penggunaan ekstraksi fitur menggunakan metode Gray-Level Co-Occurrence Matrix (GLCM) kemudian klasifikasi menggunakan metode Learning Vector Quantization (LVQ). Penelitian ini dilanjutkan dengan melakukan pencarian jurnal, buku dan hasil penelitian lain yang berhubungan dengan metode Gray-Level Co-Occurrence Matrix (GLCM), dan Learning Vector Quantization (LVQ). Fokus lireatur yang dicari adalah ekstraksi fitur dengan metode GrayLevel Co-Occurrence Matrix lalu klasifikasi menggunakan Learning Vector Quantization. Tahapan ini ditujukan untuk mengumpulkan referensi yang relevan sehingga penelitian ini dapat memberikan kontribusi penelitian yang baru dan memiliki dasar yang kuat.

\section{2 Studi Literatur}

Pada tahapan ini mencari referensi dengan membaca buku, jurnal, dan referensi dari media internet untuk memperoleh pengertian dan pengetahuan mengenai ekstraksi fitur menggunakan Gray Level Co-Occurrence Matrix (GLCM). Adapun yang membedakan penelitian ini dengan peneilian sebelumnya yaitu, pada penelitian ini menggunakan metode Learning Vector Quantization (LVQ), bahasa pemrograman python, dan metode Gray Level Co-Occurrence Matrix sebagai ekstraksi fitur.

\subsubsection{Gray Level Co-Occurrence Matrix (GLCM)}

Gray Level Co-occurrence Matrix (GLCM) adalah salah satu metode yang digunakan untuk melakukan analisis tekstur atau ekstraksi ciri. Gray Level Co-Occurrence Matrix (GLCM) 
merupakan sebuah matriks yang merepresentasikan frekuensi munculnya pasangan 2 (dua) piksel yang memiliki intensitas tertentu dengan arah dan jarak tertentu.

$$
\begin{aligned}
\operatorname{GLCM} \vec{r} \quad(i, j)=\left|I(x, y), I\left(x_{i}, y_{j}\right)\right| \vec{r}=\sqrt{\left(x_{j}-x_{i}\right)^{2}+\left(y_{j}-y_{i}\right)^{2}, i, j \in N} \\
\text { untuk } 0 \leq \mathrm{I}(\mathrm{x}, \mathrm{y}) \leq 255
\end{aligned}
$$

Untuk mendapatkan fitur Gray Level Co-Occurrence Matrix (GLCM), hanya beberapa besaran yang diusulkan Haralick yang dipakai. Sebagai contoh Newsam dan Kammath (2005) hanya menggunakan lima besaran untuk Gray Level Co-Occurrence Matrix (GLCM) berupa angular second moment (ASM), contrast, inverse different moment (IDM), entropy, dan correlation.

1. ASM (Angular Second Moment)

ASM digunakan untuk mengukur tentang kesamaan citra dihitung dengan cara sebagai berikut:

$$
\mathrm{ASM}=\sum_{i=1}^{L} \sum_{j=1}^{L}\left(\operatorname{GLCM}(i, j)^{2}\right)
$$

2. Kontras (Contrast)

Contrast digunakan untuk mengukur frekuensi spasial dari citra dan perbedaan momen Gray Level Co-Occurrence Matrix (GLCM). Contrast merupakan ukuran keberadaan variasi aras keabuan pixel citra dihitung dengan cara sebagai berikut:

$$
\text { CONTRAST }=\sum_{n=1}^{L} n^{2}\left\{\sum_{|i-j|} \operatorname{GLCM}(i, j)\right\}
$$

3. IDM (Inverse Difference Momentum)

IDM digunakan untuk mengukur homogenitas dihitung dengan cara sebagai berikut:

$$
\mathrm{IDM}=\sum_{i=1}^{L} \sum_{j=1}^{L} \frac{\operatorname{GLCM}(i, j)}{1+(i-j)^{2}}
$$

4. Entropi (Entropy)

Entropi menyatakan ukuran ketidakteraturan bentuk dan derajat keabuan yang dihitung dengan cara sebagai berikut:

$$
\text { ENTROPY }=-\sum_{i=1}^{L} \sum_{j=1}^{L}((\operatorname{GLCM}(i, j))(\log (\operatorname{GLCM}(i, j)))
$$

5. Korelasi (Correlation)

Korelasi merupakan ukuran ketergantungan linier antar nilai aras keabuan dalam citra dihitung dengan menggunakan rumus:

$$
\text { CORRELATION }=\frac{\sum_{i=1}^{L} \sum_{j=1}^{L}\left(i-\mu_{i}^{\prime}\right)\left(i-\mu_{j}^{\prime}\right)(\operatorname{GLCM}(i, j))}{\sqrt{\sigma_{i}^{2} \sigma_{j}^{2}}}
$$

Dengan,

$$
\begin{aligned}
\mu_{i}^{\prime} & =\sum_{i=1}^{L} \sum_{j=1}^{L}(i)(\operatorname{GLCM}(i, j)) \\
\mu_{j}^{\prime} & =\sum_{i=1}^{L} \sum_{j=1}^{L}(j)(\operatorname{GLCM}(i, j)) \\
\sigma_{i}^{2} & =\sum_{i=1}^{L} \sum_{j=1}^{L}\left((\operatorname{GLCM}(i, j))\left(i-\mu_{i}^{\prime}\right)^{2}\right) \\
\sigma_{j}^{2} & =\sum_{i=1}^{L} \sum_{j=1}^{L}\left((\operatorname{GLCM}(i, j))\left(j-\mu_{i}^{\prime}\right)^{2}\right)
\end{aligned}
$$

\subsubsection{Learning Vector Quantization (LVQ)}

Learning Vector Quantization (LVQ) merupakan metode klasifikasi berbasis jaringan syaraf tiruan yang mengimplementasikan konsep kompetisi. Kompetisi pada Learning Vector Quantization (LVQ) hanya ada satu neuron pemenang dalam proses kompetisi. Learning Vector 
Quantization (LVQ) lebih unggul dari segi kecepatan, dibandingkan dengan jaringan syaraf tiruan lainnya.

Jaringan Learning Vector Quantization (LVQ) merupakan yang terdiri dari lapisan kompetisi, selain lapisan input. Arsitektur Learning Vector Quantization (LVQ) ditampilkan pada Gambar 2.3. Banyaknya neuron pada lapisan input sesuai dengan banyaknya fitur pada setiap data. Neuron yang ada pada lapisan kompetisi akan diberi sebuah label atau kelas sesuai dengan kelas yang ada pada data, umumnya beberapa neuron yang ada pada lapisan kompetisi berisi kelas yang sama. Sehingga, banyaknya neuron yang ada pada lapisan kompetisi tidak sama dengan banyaknya kelas pada data(Sigit Adinugroho dan Yuita Arum Sari, 2017).

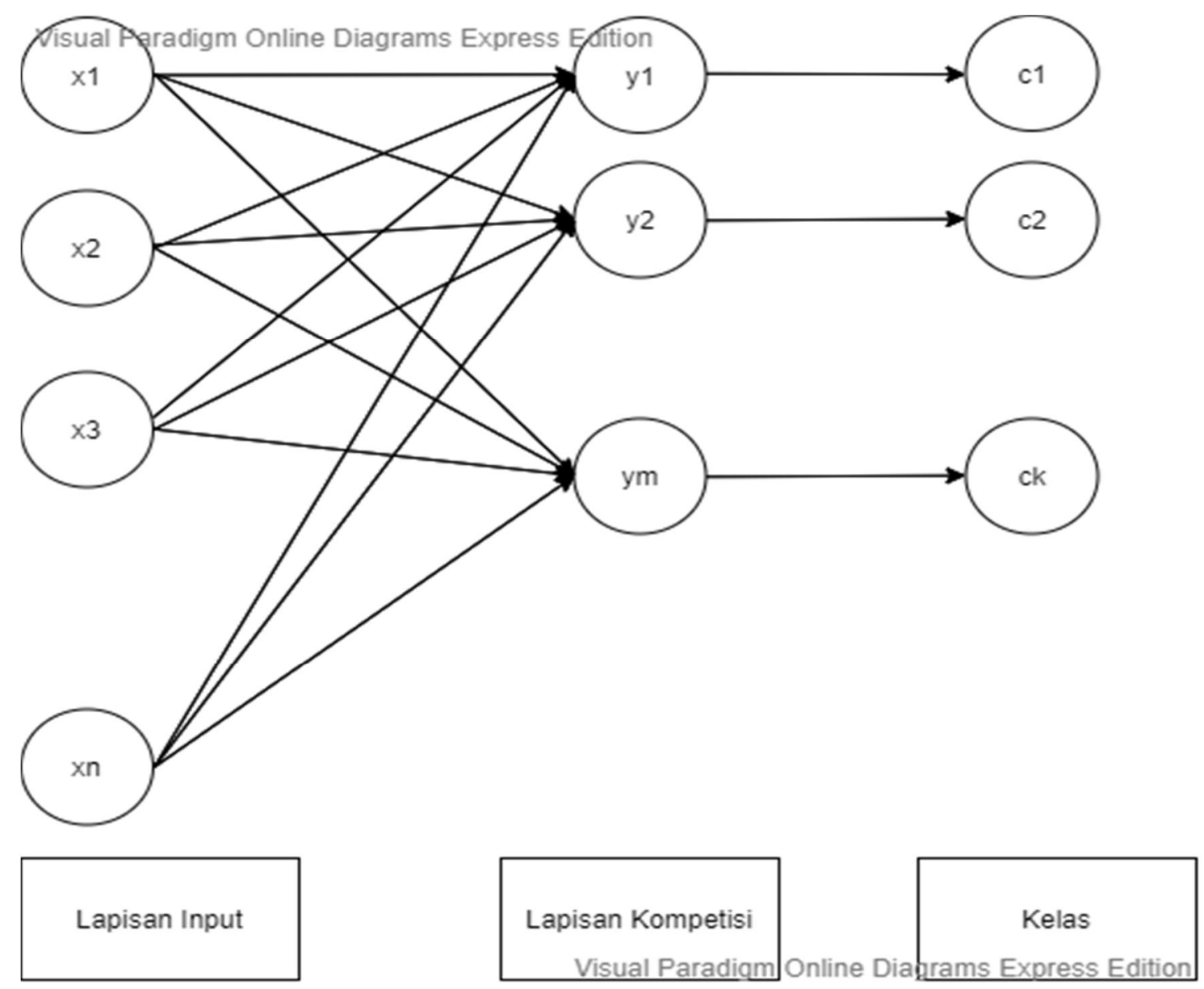

Gambar 2. Arsitektur LVQ

Algoritmanya adalah sebagai berikut (Laurent, 1994):

1. Tentukan maksimum epoch (banyaknya proses pelatihan yang akan diulangi), eps (error minimum yang diinginkan), dan nilai alpha.

2. Hasil ekstraksi ciri pertama dari masing-masing pola digunakan sebagai data awal (inisialisasi). Data inisialisasi ini akan diisi sebagai nilai bobot awal (w).

3. Epoch $=0$

4. Selama (Epoch < MaxEpoch) atau (alpha > eps), maka lakukan:

a. Epoch $=$ epoch +1

b. Untuk setiap data hasil ekstraksi ciri, lakukan hal berikut:

1. Set $x=$ hasil ekstraksi ciri dari pola

2. Set $\mathrm{T}=$ nomor urut dari setiap kelas. 
3. Hitung jarak hasil ekstraksi ciri pola saat ini dengan masing-masing bobot. Misalkan dihitung jarak hasil ekstraksi ciri pada pola pertama dengan setiap bobot, maka rumus yang digunakan adalah sebagai berikut:

$\begin{array}{lll}\text { Dengan: } & & \\ \mathrm{x} 1 \mathrm{~m} & = & \text { Bit ektraksi ciri pola-1 yang ke-m } \\ \mathrm{w} 1 \mathrm{~m} & = & \text { Bobot } \mathrm{W}(1, \mathrm{~m}) \\ \mathrm{m} & = & \text { Banyak bit ekstraksi ciri }\end{array}$

$$
\text { Jarak }=\sqrt{\left(x_{11}+w_{11}\right)^{2}+. .+\left(x_{1 m}+w_{1 m}\right)^{2}}
$$

Bila nomor kelas pada bobot yang memiliki jarak terkecil sama dengan nilai nomor urut $(\mathrm{T})$ pola, maka hitung:

$\mathrm{w}_{\mathrm{j}(\text { baru }}=\mathrm{w}_{\mathrm{j}(\mathrm{lama})}+\alpha\left(\mathrm{x}-\mathrm{w}_{\mathrm{j}(\mathrm{lama})}\right)$

5. Bila tidak, maka hitung:

$\mathrm{w}_{\mathrm{j} \text { (baru) }}=\mathrm{w}_{\mathrm{j} \text { (lama) }}-\alpha\left(\mathrm{x}-\mathrm{w}_{\mathrm{j}(\text { lama })}\right)$

c. Kurangi nilai alpha:

$\alpha=\alpha-(0.1 * \alpha)$ (Ahmad sahru Romadhon \& Vivi Tri Widyaningrum, 2015).

2.3 Pengumpulan Data

Pada tahapan ini dilakukan pengumpulan data, objek citra yang digunakan adalah citra pneumonia yang didapat dari situs kaggle yaitu Chest X-Ray Images (Pneumonia). Dataset yang digunakan adalah data yang tersedia secara public dapat dilihat dari https://www.kaggle.com/paultimothymooney/chest-xray-pneumonia.

\subsection{Perancangan}

Pada tahap ini dilakukan perancangan sistem, dengan melakukan pengkodean yaitu resize citra paru-paru, kemudian dilanjutkan dengan proses ekstraksi fitur menggunakan Gray Level Co-Occurrence Matrix, selanjutnya hasil ekstraksi fitur akan dilakukan training menggunakan Learning Vector Quantization (LVQ). Tahapan yang dilakukan setelah ini yaitu, tahapan pelatihan data (data training) dan pengujian data (data testing). Proses data training dilakukan dengan menentukan jenis citra $x$-rays paru-paru, kemudian dilakukan resize, dan citra diekstraksi menggunakan Gray Level Co-Occurrence Matrix (GLCM) menggunakan sudut yaitu $0^{\circ}, 45^{\circ}, 90^{\circ}$, dan $135^{\circ}$, kemudian hasil ekstraksi untuk masing-masing sudut terdapat 2 ektraksi yaitu, train, dan test untuk dilakukan klasifikasi menggunakan metode Learning Vector Quantization (LVQ).

\subsection{Implementasi}

Pada tahap ini dilakukan implementasi terhadap perancangan yang telah dibuat kedalam pengkodean python.

\subsection{Pengujian}

Pada tahap ini dilakukan proses pengujian pada data train dan data test secara acak untuk mendapatkan hasil dan akurasi. Data train yang diguanakan untuk pengujian sebanyak 1400 gambar, dan data test yang digunakan untuk pengujian sebanyak 400 gambar. Pengujian dilakukan dengan menggunakan metode Learning Vector Quantization sebagai metode untuk klasifikasi dengan menggunakan Gray Level Co-Occurrence Matrix sebagai ekstraksi fitur.

\section{HASIL DAN PEMBAHASAN}

Pada tahap ini membahas tentang implementasi dimana terdapat penjelasan mengenai proses diantaranya Resize, ektraksi fitur Gray Level Co-Occurrence Matrix (GLCM), klasifikasi 
menggunakan Learning Vector Quantization (LVQ), serta membahas hasil pengujian dari klasifikasi pneumonia.

\subsection{Resize}

Tujuan melakukan resize untuk mengubah ukuran citra agar setiap input citra memiliki resolusi yang sama rata dengan ukuran 300 x 300 piksel sehingga mendapatkan hasil citra yang diperlukan.

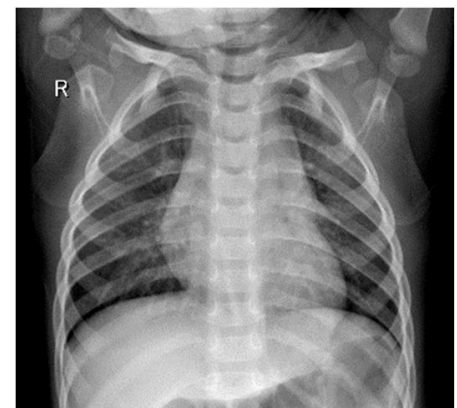

Sumber: kaggle.com/paultimothymooney/chest-xray-pneumonia

\section{Gambar 3. Citra Asli}

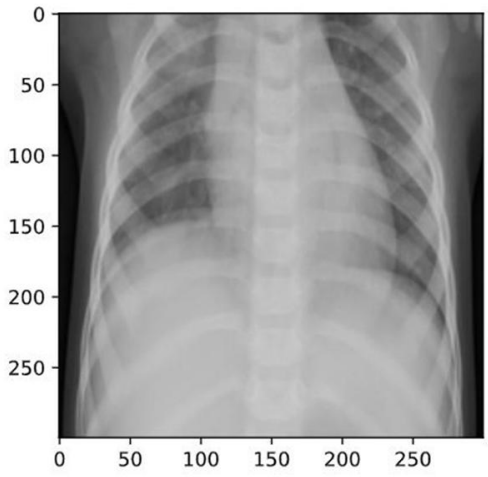

\section{Gambar 4. Citra Setelah di-Resize}

\subsection{Impelmentasi Ekstraksi Gray Level Co-Occurrence Matrix (GLCM)}

Tahap ini adalah proses melakukan ekstraksi fitur menggunakan Gray Level CoOccurrence Matrix (GLCM) untuk setiap data train dan data test. Proses ini menggunakan citra $x$-rays paru-paru yang telah dilakukan resize dengan ukuran $300 \times 300$ piksel dengan empat (4) sudut yaitu $\left(0^{\circ}, 45^{\circ}, 90^{\circ}\right.$ dan $\left.135^{\circ}\right)$. Proses berikutnya dibentuk matriks dengan kookurasi dengan menghitung frekuensi kemunculan pasangan nilai keabuhan piksel referensi dan piksel tetangga pada jarak dan arah yang telah ditentukan. Setelah itu dilakukan perhitungan ciri statistik pada Gray Level Co-Occurrence Matrix dari citra, kategori citra dikategorikan menjadi 4 (empat) ciri terdiri dari kontras, energi, homogenitas, dan korelasi.

\subsection{Implementasi Klasifikasi Learning Vector Quantization (LVQ)}

Tahap ini adalah proses melakukan klasifikasi dengan menerapkan metode Learning Vector Quantization (LVQ) untuk mendapatkan hasil dari klasifikasi dalam pengujian (testing). Pertama dilakukan pemisahan dataset menggunakan cross validation, kemudian dilanjutkan dengan melakukan evaluasi algoritma menggunakan cross validation. Kemudian dilakukan perhitungan jarak euclidean antara 2 (dua) vector, selanjutnya dibuat prediksi dengan menggunakan vector. Langkah selanjutnya menyiapkan dan memuat data yang akan diklasifikasi, kemudian mengubah kolom kelas menjadi bilangan bulat dari hasil ekstraksi 
GLCM, dan dilakukan evaluasi algoritma. Nilai learning rate yang akan digunakan pada penelitian ini yaitu 0,1 sampai dengan 1 .

Hasil dari proses evaluasi berupa mean accuracy dimana mean accuracy digunakan untuk melakukan perbandingan rasio antara data train dan data test.

\subsection{Hasil Klasifikasi Learning Vector Quantization (LVQ)}

Setelah dilakukan implementasi klasifikasi Learning Vector Quantization (LVQ), selanjutnya didapat hasil berupa Confusion Matrix.

\subsubsection{Confusion Matrix Learning rate $=0,4$}

Tahap ini adalah tahapan Confusion Matrix utnuk mendapatkan sebuah nilai atau hasil prediksi dengan menggunakan metode ekstraksi fitur Gray Level Co-Occurrence Matrix (GLCM) dan klasifikasi Learning Vector Quantization (LVQ), sehingga didapat hasil akurasi data train tertinggi pada learning rate $=0,4$, epoch $=200$ sebesar $89,714 \%$. Selanjutnya tingkat keberhasilan dari metode yang digunakan, dihitung dengan menggunakan metode Confusion Matrix, dimana nilai yang dihitung berupa nilai Accuraccy, Precission, dan Recall cara perhitungan dapat dilihat pada Tabel 1 dan persamaan (1),(2),(3). Hasil pengujian data test learning rate $=0,4$ dapat dilihat pada Tabel 2 dan grafik perbandingan accuracy learning rate 0,4 dapat dilihat pada Gambar 5.

Tabel 1. Confusion Matrix

\begin{tabular}{|c|c|c|c|}
\hline \multirow{4}{*}{ 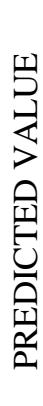 } & & \multicolumn{2}{|c|}{ ACTUAL VALUE } \\
\hline & & Positive & Negative \\
\hline & : & $\begin{array}{c}\text { TP } \\
\text { True Positive }\end{array}$ & $\begin{array}{c}\text { FP } \\
\text { False Positive }\end{array}$ \\
\hline & 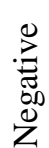 & $\begin{array}{c}\text { FN } \\
\text { False Negavite }\end{array}$ & $\begin{array}{c}\text { TN } \\
\text { True Negative }\end{array}$ \\
\hline
\end{tabular}

$$
\begin{aligned}
& \text { Presision }=\frac{T P}{T P+F P} \\
& \text { Recall }=\frac{T P}{T P+F N} \\
& \text { Accuracy }=\frac{T P+T N}{T P+T N+F P+F N}
\end{aligned}
$$

Keterangan:

True Positive (TP): Jumlah data positif citra yang terklasifikasi dengan benar oleh sistem.

True Negative (TN): Jumlah data negatif citra yang terklasifikasi dengan benar oleh sistem.

False Positive (FP): Jumlah data positif citra yang terklasifikasi salah oleh sistem.

\begin{tabular}{|c|c|c|c|c|c|c|c|c|c|c|}
\hline Test & \multicolumn{2}{|c|}{$N \_$folds 1} & \multicolumn{2}{|c|}{$N$ folds 2} & \multicolumn{2}{|c|}{ N_folds 3} & \multicolumn{2}{|c|}{$N \_$folds 4} & \multicolumn{2}{|c|}{$N$ folds 5} \\
\hline LVQ- & 30 & 10 & 31 & 8 & 32 & 11 & 28 & 14 & 29 & 7 \\
\hline GLCM-45 ${ }^{\circ}$ & 9 & 31 & 12 & 29 & 11 & 26 & 10 & 28 & 12 & 32 \\
\hline Presision & \multicolumn{2}{|c|}{$75 \%$} & \multicolumn{2}{|c|}{$79 \%$} & \multicolumn{2}{|c|}{$74 \%$} & \multicolumn{2}{|c|}{$67 \%$} & \multicolumn{2}{|c|}{$81 \%$} \\
\hline Recall & \multicolumn{2}{|c|}{$77 \%$} & \multicolumn{2}{|c|}{$72 \%$} & \multicolumn{2}{|c|}{$74 \%$} & \multicolumn{2}{|c|}{$74 \%$} & \multicolumn{2}{|c|}{$71 \%$} \\
\hline Accuracy & \multicolumn{2}{|c|}{$76,250 \%$} & & & \multicolumn{2}{|c|}{$72,500 \%$} & \multicolumn{2}{|c|}{$70,000 \%$} & \multicolumn{2}{|c|}{$76,250 \%$} \\
\hline $\begin{array}{l}\text { Mean } \\
\text { Accuracy }\end{array}$ & \multicolumn{10}{|c|}{$74,000 \%$} \\
\hline
\end{tabular}

False Negative (FN): Jumlah data negatif citra yang terklasifikasi salah oleh sistem.

Tabel 2. Hasil Pengujian Data Test Learning Rate $=0,4$ sudut $45^{\circ}$ 
Berdasarkan Tabel 2, pengujian yang dilakukan dengan learning rate $=0.4, n \_$epoch $=$ $200, n \_$folds $=5$. Pada setiap kolom $n \_$folds dimana masing-masing $n \_$folds berisi 2 baris dan 2 kolom untuk memberikan hasil akurasi dimana kolom 1 baris ke 1 dari masing-masing $n$ folds menunjukkan jumlah nilai dari setiap jenis citra yang dapat dikenali (TP) menggunakan fitur Gray Level Co-Occurrence Matrix, kolom 2 baris ke 1 dari masing-masing $n_{-}$folds menunjukkan jumlah nilai dari setiap jenis citra yang tidak dapat dikenali (FP), untuk baris 2 kolom 1 dari masing-masing $n \_$folds menunjukkan jumlah data negatif yang terklasifikasi salah oleh sistem (FN), sedangkan baris 2 kolom ke 2 dari masing-masing $n \_$folds menunjukkan jumlah data negatif citra yang terklasifikasi benar oleh sistem (TN).

Jumlah data test 400 gambar dibagi menjadi 5 kelompok (folds) masing-masing $n$ folds terdiri dari 80 data citra, untuk data test dengan sudut $45^{\circ}$ n_folds yang pertama dapat mengenali 30 citra $x$-rays paru-paru normal dan 31 citra $x$-rays paru-paru pneumonia dari 80 citra didapat Accuracy sebesar 76,250\%, nilai precission $=75 \%$, dan nilai recall $=77 \%$. Untuk $n \_$fold yang kedua dapat mengenali 31 citra $x$-rays paru-paru normal dan 29 citra $x$-rays paruparu pneumonia dari 80 citra didapat Accuracy sebesar 75,000\%, nilai precission $=79 \%$, nilai recall $=72 \%$. Untuk $n$ fold yang ketiga dapat mengenali 32 citra $x$-rays paru-paru normal dan 26 citra $x$-rays paru-paru pneumonia dari 80 citra didapat Accuracy sebesar 72,500\%, nilai precission $=74 \%$, nilai recall $=74 \%$. Untuk $n \_$fold yang keempat dapat mengenali 28 citra $x$ rays paru-paru normal dan 28 citra $x$-rays paru-paru pneumonia dari 80 citra didapat Accuracy sebesar $70,000 \%$, nilai precission $=67 \%$, nilai recall $=74 \%$. Untuk $n$ fold yang kelima dapat mengenali 29 citra $x$-rays paru-paru normal dan 32 citra $x$-rays paru-paru pneumonia dari 80 citra didapat Accuracy sebesar $76,250 \%$, nilai precission $=81 \%$, nilai recall $=71 \%$, dari keseluruhan Accuracy yang didapat mean accuracy $=74,000 \%$.

Accuracy

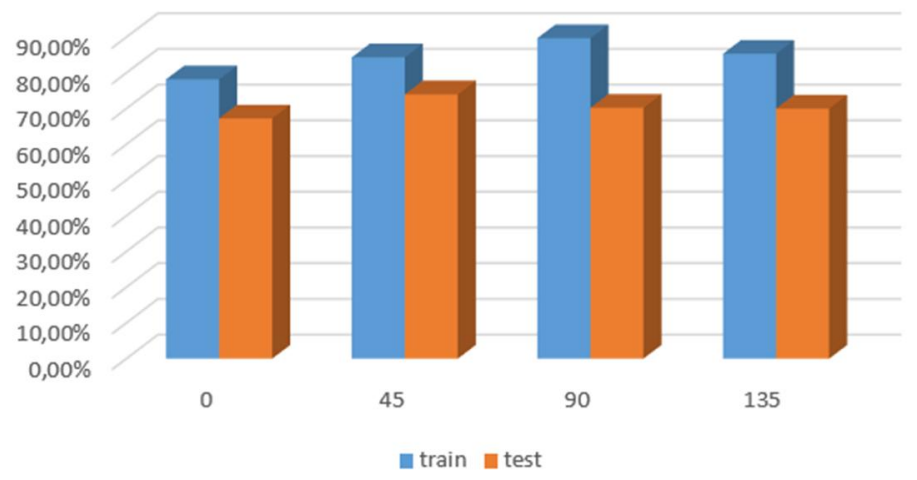

Gambar 5. Grafik Perbandingan Accuracy Learning Rate $=0,4$

Berdasarkan grafik pada Gambar 5 dapat disimpulkan bahwa dengan learning rate $=0.4$ dengan menggunakan resize pada citra $x$-rays paru-paru didapatkan hasil Accuracy tertinggi yaitu untuk data train pada sudut $90^{\circ}$ sebesar $89,714 \%$. Hasil accuracy tertinggi yang didapatkan untuk data test yaitu pada sudut $45^{\circ}$ yang berhasil mengenali sebanyak 30 citra $x$ rays paru-paru normal dan 31 citra $x$-rays paru-paru pneumonia dari 80 citra untuk fold pertama dengan accuracy 76,250\%, untuk fold kedua berhasil mengenali 31 citra $x$-rays_paru-paru normal dan 29 citra $x$-rays paru-paru pneumonia dari 80 citra dengan accuracy 75,000\%, untuk fold ketiga berhasil mengenali 32 citra $x$-rays_paru-paru normal dan 26 citra $x$-rays paru-paru pneumonia dari 80 citra dengan accuracy 72,500\%, untuk fold keempat berhasil mengenali 28 citra $x$-rays_paru-paru normal dan 28 citra $x$-rays paru-paru pneumonia dari 80 citra dengan accuracy 70,000\%, untuk fold kelima berhasil mengenali 29 citra $x$-rays_paru-paru normal dan 32 citra $x$-rays paru-paru pneumonia dari 80 citra dengan accuracy $76,250 \%$.

\section{KESIMPULAN}


Berdasarkan hasil penelitian menggunakan metode Gray Level Co-Occurrence Matrix dan Learning Vector Quantization untuk klasifikasi pneumonia dapat disimpulkan sebagai berikut:

1. Dengan melakukan proses resize pada citra $x$-rays paru-paru dapat meningkatkan hasil akurasi.

2. Dengan menggunakan metode ekstraksi fitur Gray Level Co-Occurrence Matrix (GLCM) dan metode klasifikasi Learning Vector Quantizationi (LVQ) untuk learning rate $=0.4$ mendapatkan akurasi data train tertinggi sebesar $89,714 \%$ dan akurasi data test tertinggi sebesar $74,000 \%$.

3. Dengan menggunakan epoch $=200$ pada proses klasifikasi dapat meningkatkan hasil akurasi.

4. Dengan menggunakan $k$-fold sebanyak 5 dapat meningkatkan akurasi data test yang terdiri dari 400 citra $x$-rays paru-paru normal dan pneumonia sehingga data dikelompokkan menjadi 5 dengan masing-masing kelompok atau fold terbagi menjadi 80 citra $x$-rays paru-paru.

\section{SARAN}

Berdasarkan penelitian yang telah dilakukan adapun beberapa saran dari penulis yang telah didapatkan untuk memberikan saran untuk peneliti selanjutnya diantara sebagai berikut:

1. Melakukan pengujian dengan jumlah $k \_$fold yang berbeda untuk memperoleh hasil yang lebih baik.

2. Melakukan pengujian dengan menggunakan metode ekstraksi fitur yang berbeda untuk mendapatkan hasil akurasi yang lebih baik.

3. Melakukan pengujian dengan menggunakan learning rate yang berbeda untuk memeperoleh hasil yang lebih baik.

\section{DAFTAR PUSTAKA}

[1] S. \&. S. A. Y. Adinugroho. 2017, "Perbandingan Jaringan Learning Vector Quantization dan Backpropagation pada Klasifikasi Daun Berbasiskan Fitur Gabungan.," JURNAL INFORMATIKA \& MULTIMEDIA, pp. 58-62.

[2] E. \&. S. Afriandi. 2016, "Identifikasi Telapak Tangan Menggunakan Jaringan Syaraf Tiruan Learning Vector Quantization (LVQ)," Jurnal Infotel.

[3] M. Brammer, 2007, Principles of Data Mining, London: Springer-Verlag,

[4] L. A. D. \&. Y. Clauditta., "Menghitung Jumlah Orang Dengan Ekstraksi Fitur Gray Level CoOccurrence Matrix (GLCM)," STMIK GI MDP Palembang, pp. 3-5.

[5] A. A. \&. H. A. Kasim. 2014, "Klasifikasi Citra Batik Menggunakan Jaringan Syaraf Tiruan Berdasarkan Gray Level Co-Occurrence Matrix (GLCM)," Seminar Nasional Aplikasi Teknologi Informasi (SNATI), pp. i-7.

[6] A. Z. \&. A. N. S. Leleury, 2016, "Perancangan Sistem Diagnosa Penyakit Saluran Pernapasan Menggunakan Metode Learning Vector Quantization (LVQ)," Jurnal Matematika Integratif, pp. i2.

[7] D. M. I. Maysanjaya, 2020, "Klasifikasi Pneumonia Pada Citra X-rays Paru-paru dengan 
Convolutional Neural Network," Jurnal Nasional Teknik Elektro dan Teknologi Informasi, pp. 190-192.

[8] A. K. \&. I. R. R. Neneng. 2016, "Support Vector Machine Untuk Klasifikasi Citra Jenis Daging Berdasarkan Tekstur Menggunakan Ciri Gray Level Co-Occurrence Matrices (GLCM)," Jurnal Sistem Informasi Bisnis, pp. i-2.

[9] P. C. W. T. R. R. B. A. \&. K. K. E. B, "Transfer Learning from Chest X-Ray Pre-trained Convolutional Neural Network For Learning Mammogram Data," in Procedia Computer Science, Indonesia, 2018.

[10] A. L. A. D. W. P. E. \&. M. Pariyandani. 2019, "Klasifikasi Citra Ikan Berformalin Menggunakan Metode k-NN dan GLCM," Prosiding Seminar Nasional Teknologi Informatika, pp. i-42.

[11] A. \&. Z. U. A. Perdananto. 2019, "Penerapan Deep Learning pada Aplikasi Prediksi Penyakit Pneumonia Berbasis Convolutional Neural Network," Journal of Informatics and Communications Technology (JITC), pp. i-9. 